University of Nebraska - Lincoln

DigitalCommons@University of Nebraska - Lincoln

Agronomy \& Horticulture -- Faculty Publications

Agronomy and Horticulture Department

$1-1-2000$

\title{
Using a Nitrate Specific Ion Electrode to Determine Stalk Nitrate-Nitrogen Concentration
}

Wallace Wilhelm

University of Nebraska-Lincoln, wwilhelm1@unl.edu

S.L. Arnold

University of Nebraska-Lincoln, sarnold1@unl.edu

James S. Schepers

University of Nebraska-Lincoln, james.schepers@gmail.com

Follow this and additional works at: https://digitalcommons.unl.edu/agronomyfacpub

Part of the Plant Sciences Commons

Wilhelm, Wallace; Arnold, S.L.; and Schepers, James S., "Using a Nitrate Specific Ion Electrode to Determine Stalk Nitrate-Nitrogen Concentration" (2000). Agronomy \& Horticulture -- Faculty Publications. 10.

https://digitalcommons.unl.edu/agronomyfacpub/10

This Article is brought to you for free and open access by the Agronomy and Horticulture Department at DigitalCommons@University of Nebraska - Lincoln. It has been accepted for inclusion in Agronomy \& Horticulture -Faculty Publications by an authorized administrator of DigitalCommons@University of Nebraska - Lincoln. 


\title{
NOTES \& UNIQUE PHENOMENA
}

\author{
Using a Nitrate Specific Ion Electrode \\ to Determine Stalk Nitrate-Nitrogen Concentration
}

\author{
Wallace W. Wilhelm,* S. L. Arnold, and James S. Schepers
}

\begin{abstract}
The end-of-season stalk $\mathrm{NO}_{3}$ test has been used to determine $\mathrm{N}$ sufficiency in corn (Zea mays L.). Nitrate concentration is commonly determined with flow-injection analysis (FIA), which is accurate but uses hazardous chemicals and is time-consuming. Use of a simpler method of $\mathrm{NO}_{3}$ determination, such as the $\mathrm{NO}_{3}$ specific ion electrode (SIE), may save time and costs, and reduce hazards. The objective of this study was to compare estimates of stalk $\mathrm{NO}_{3}$ concentration by FIA and $\mathrm{NO}_{3}$ SIE. For FIA, $\mathrm{NO}_{3}$ was extracted with $2 M \mathrm{KCl}$, and the extract was filtered before analysis. For $\mathrm{SIE}, \mathrm{NO}_{3}$ was extracted with $0.04 M\left(\mathrm{NH}_{4}\right)_{2} \mathrm{SO}_{4}$, and the extract was analyzed without filtration. The slope of the linear regression between concentrations estimated by SIE and FIA did not differ from 1.0. Use of the $\mathrm{NO}_{3}$ SIE, compared with FIA, reduces costs, sample processing, and use of hazardous chemicals.
\end{abstract}

$\mathrm{T}$ HE END-OF-SEASON corn stalk $\mathrm{NO}_{3}$ test was proposed and advocated by Binford et al. (1990) as a method of determining if excessive or insufficient $\mathrm{N}$ was available to the corn crop during the latter part of the season. In the test, $20-\mathrm{cm}$ segments of corn stalks (between 10 and $30 \mathrm{~cm}$ above the soil) are collected from several plants $(\approx 10)$, dried, ground, and analyzed for $\mathrm{NO}_{3}-\mathrm{N}$. Nitrate $\mathrm{N}$ concentrations less than about $700 \mathrm{mg} \mathrm{kg}^{-1}$ plant tissue indicate that available $\mathrm{N}$ limited grain yield; $\mathrm{NO}_{3}-\mathrm{N}$ concentrations above $2000 \mathrm{mg} \mathrm{kg}^{-1}$ indicate that excessive amounts of $\mathrm{N}$ were available to the crop (Binford et al., 1992). Other researchers have evaluated the proposed test and concur that when end-of-season stalk $\mathrm{NO}_{3}$ concentrations are great $\left(>2000 \mathrm{mg} \mathrm{kg}^{-1}\right)$, excessive levels of $\mathrm{N}$ were available to the crop (Varvel et al., 1997). These studies suggest that the end-of-season corn stalk $\mathrm{NO}_{3}$ test can be used as a postmortem to determine if yield-limiting or excessive $\mathrm{N}$ was present. Historical knowledge of crop $\mathrm{N}$ need may be used by producers to guide future fertilizer- $\mathrm{N}$ management, thereby improving profitability and reducing environmental degradation.

In the initial publications on use of the end-of-season stalk $\mathrm{NO}_{3}$ test, Binford et al. $(1990,1992)$ reported using the $\mathrm{MgO}-\mathrm{Devarda}$ alloy steam-distillation procedure (Keeney and Nelson, 1982) and the Lachat ${ }^{1}$ flow-injec-

\footnotetext{
${ }^{1}$ Mention of commercial products in this paper is solely to provide specific information for the reader. It does not constitute endorsement by the USDA-ARS or University of Nebraska's Agricultural Research Division over other products that may be suitable.

USDA-ARS, 119 Keim Hall, Univ. of Nebraska, Lincoln, NE 685830934. Joint contribution of the USDA-ARS and the Agric. Res. Division of the Univ. of Nebraska. Published as Journal Series no. 12603. Received 4 May 1999. *Corresponding author (wwilhelm1@unl.edu).
}

Published in Agron. J. 92:186-189 (2000). tion procedure (Lachat Instruments, Milwaukee; Method 12-107-04-1-B) to determine $\mathrm{NO}_{3}$ concentration in aliquots of filtered extracts prepared by shaking known weights of ground stalk material for $30 \mathrm{~min}$ in $100 \mathrm{~mL}$ of $2 M \mathrm{KCl}$. Though accurate, these analytical procedures are expensive, time-consuming, and employ hazardous chemicals (strong acids and bases and $\mathrm{Cd}$ ).

Given that the goal of the stalk $\mathrm{NO}_{3}$ test is to determine if stalk $\mathrm{NO}_{3}-\mathrm{N}$ concentrations are less than 700 $\mathrm{mg} \mathrm{kg}^{-1}$ or greater than $2000 \mathrm{mg} \mathrm{kg}^{-1}$, it seems logical that a somewhat less accurate procedure could provide essentially the same information, with the possibility of saving time and laboratory resources and avoiding safety and environmental hazard issues. A candidate procedure that is less expensive and less time-consuming, but may be less accurate, is the use of a $\mathrm{NO}_{3}$ SIE. The object of this study was to compare stalk $\mathrm{NO}_{3}$ concentration determined by the flow-injection method and $\mathrm{NO}_{3}$ SIE techniques.

\section{MATERIALS AND METHODS}

Shortly after physiological maturity, stalk samples were collected from 10 corn plants in a crop sequence $X$ inbred line $\times$ $\mathrm{N}$ rate experiment initiated to determine the optimum rate of $\mathrm{N}$ fertilizer application for hybrid seed production fields (Wilhelm and Johnson, 1997). Twenty-two (Table 1) of these samples were selected for use in this study to compare methods of determining stalk $\mathrm{NO}_{3}$ concentration. Samples were selected a priori to represent the range of treatment combinations in the study, and therefore were assumed to provide samples covering the range of stalk $\mathrm{NO}_{3}$ concentrations found in producers' fields.

Stalk segments were 10 to $20 \mathrm{~cm}$ in length and came from the base of the stalk, from 0 to $25 \mathrm{~cm}$ above the soil surface. At sampling time, all plants in a 3.1-m segment of row were cut at the soil surface and moved to the field edge. Ten of these plants were selected at random and a stalk segment was taken from each. Each stalk segment was composed of one node and one internode (Fig. 1). Individuals collecting the samples estimated the fraction of total length of internode between the lowest node and the cut end of the stalk on each sampled plant. The length of internode above the lowest node needed to represent the complement of the fraction below the node was estimated and the stalk cut at that point. In the example shown in Fig. 1, about 0.3 of the internode below the lowest node remained on the stalk as it was removed from the field. To collect the equivalent of one internode, 0.7 of the internode above the lowest node was estimated and the

Abbreviations: FIA, flow-injection analysis; SIE, specific ion electrode. 
stalk cut at that point. In so doing, each stalk segment was composed of one node and one internode, but part of the internode portion of the sample came from the internode below the node and part from the internode above the node. This sampling procedure was used so that differences in $\mathrm{NO}_{3}$ concentration between node and internode tissue and differences in length of internodes would not influence estimates of the stalk $\mathrm{NO}_{3}$ concentration. Stalk segments were dried at about $60^{\circ} \mathrm{C}$ and ground with a Wiley mill to pass a 2-mm screen before extraction and $\mathrm{NO}_{3}$ analysis.

In this paper we will use the term FIA to mean the automated procedure for $\mathrm{NO}_{3}$ analysis defined by Lachat Instruments (Milwaukee, WI; Method 12-107-04-1-B). This procedure is a modification of the Griess-Ilosvay method (Keeney and Nelson, 1982). Nitrate was extracted by shaking a 0.25 -g sample of ground stalk tissue for $30 \mathrm{~min}$ with $100 \mathrm{~mL}$ of $2 \mathrm{M} \mathrm{KCl}$. Extraction media were filtered through Whatman No. 1 paper before analysis with the flow-injection procedure.

For the $\mathrm{NO}_{3}$ SIE method, $0.25 \mathrm{~g}$ of stalk tissue was shaken with $50 \mathrm{~mL}$ of $0.04 \mathrm{M}\left(\mathrm{NH}_{4}\right)_{2} \mathrm{SO}_{4}$ for $30 \mathrm{~min}$. This extraction medium was chosen because it is one of many possible weak salt solutions that could be used to extract $\mathrm{NO}_{3}$ from plant tissue and is the solution used in the outer chamber of the reference electrode. If water were used as the extraction medium, equal parts of extractant and $0.08 M\left(\mathrm{NH}_{4}\right)_{2} \mathrm{SO}_{4}$ would be combined to determine $\mathrm{NO}_{3}$ concentration with the $\mathrm{NO}_{3}$ SIE. By using $0.04 M\left(\mathrm{NH}_{4}\right)_{2} \mathrm{SO}_{4}$, the need to filter the media was also eliminated, because the electrode could be placed directly into the extraction medium to determine $\mathrm{NO}_{3}$ concentration. Reference and $\mathrm{NO}_{3} \mathrm{SIE}$ (Orion Research, Boston) were placed directly into the agitating extraction media and electrometer readings observed. Readings were recorded after
Table 1. Number of samples from each treatment in the crop sequence $\times$ inbred line $\times N$ rate experiment used to compare flow injection and nitrate specific ion electrode methods for assessing stalk $\mathrm{NO}_{3}-\mathrm{N}$ concentration.

\begin{tabular}{lllllll}
\hline & \multicolumn{7}{c}{ Samples in method comparison study } \\
\cline { 2 - 7 } Inbred $\dagger$ & $11+$ & 56 & 78 & 101 & 123 & 168 \\
\hline Continuous corn & & & & & & \\
$\quad$ FR1075 & 0 & 1 & 1 & 0 & 0 & 1 \\
$\quad$ P38 & 1 & 2 & 1 & 0 & 1 & 1 \\
$\quad$ R03 & 1 & 1 & 1 & 1 & 2 & 0 \\
Corn-soybean rotation & & & & & 0 & 1 \\
$\quad$ FR1075 & 0 & 1 & 0 & 0 & 0 & 0 \\
P38 & 0 & 0 & 0 & 0 & 0 & 1 \\
R03 & 0 & 0 & 0 & 4 & 0
\end{tabular}

$\dagger$ Source of inbreds: FR1075 from Illinois Foundation Seed, Champaign, IL, R03 and P38 from Pioneer Hi-Bred International, Johnston, IA. $\$ \mathbf{N}$ rate, $\mathbf{k g ~ h a}^{-1}$.

sequential additions of $1-\mathrm{mL}$ aliquots of $\mathrm{NO}_{3}$ interference suppressor $\left[0.0378 M\left(\mathrm{Al}_{2} \mathrm{SO}_{4}\right)_{3}, 0.0109 M \mathrm{Ag}_{2} \mathrm{SO}_{4}, 0.0257 M\right.$ $\mathrm{H}_{3} \mathrm{SNO}_{3}$, and $0.0210 M \mathrm{H}_{3} \mathrm{BO}_{3}$ ] produced no change in meter output. Several ions can influence the accuracy of $\mathrm{NO}_{3}$ concentration estimates made with $\mathrm{NO}_{3}$ SIE. The $\mathrm{NO}_{3}$ interference suppressor was used to eliminate interference from organic anions (aluminum sulfate), halogens, cyanide and sulfide ions (silver sulfate), nitrite (sulfamic acid), and carbonate and bicarbonate ions (boric acid; Orion Research, 1980).

For both analytical methods, $\mathrm{NO}_{3}-\mathrm{N}$ concentration in stalk tissue was calculated from a standard curve $\left(\mathrm{NO}_{3}-\mathrm{N}\right.$ on $\log$ scale) developed from known standards ranging in $\mathrm{NO}_{3}-\mathrm{N}$ concentration from 0 to $20 \mathrm{mg} \mathrm{kg}^{-1}$. For the FIA, standards were prepared in $2 \mathrm{M} \mathrm{KCl}$; for the $\mathrm{NO}_{3} \mathrm{SIE}$, in $0.04 \mathrm{M}$ $\left(\mathrm{NH}_{4}\right)_{2} \mathrm{SO}_{4}$. Analysis of variance, regression analysis, and $t$-tests were used to determine if the two methods differed in

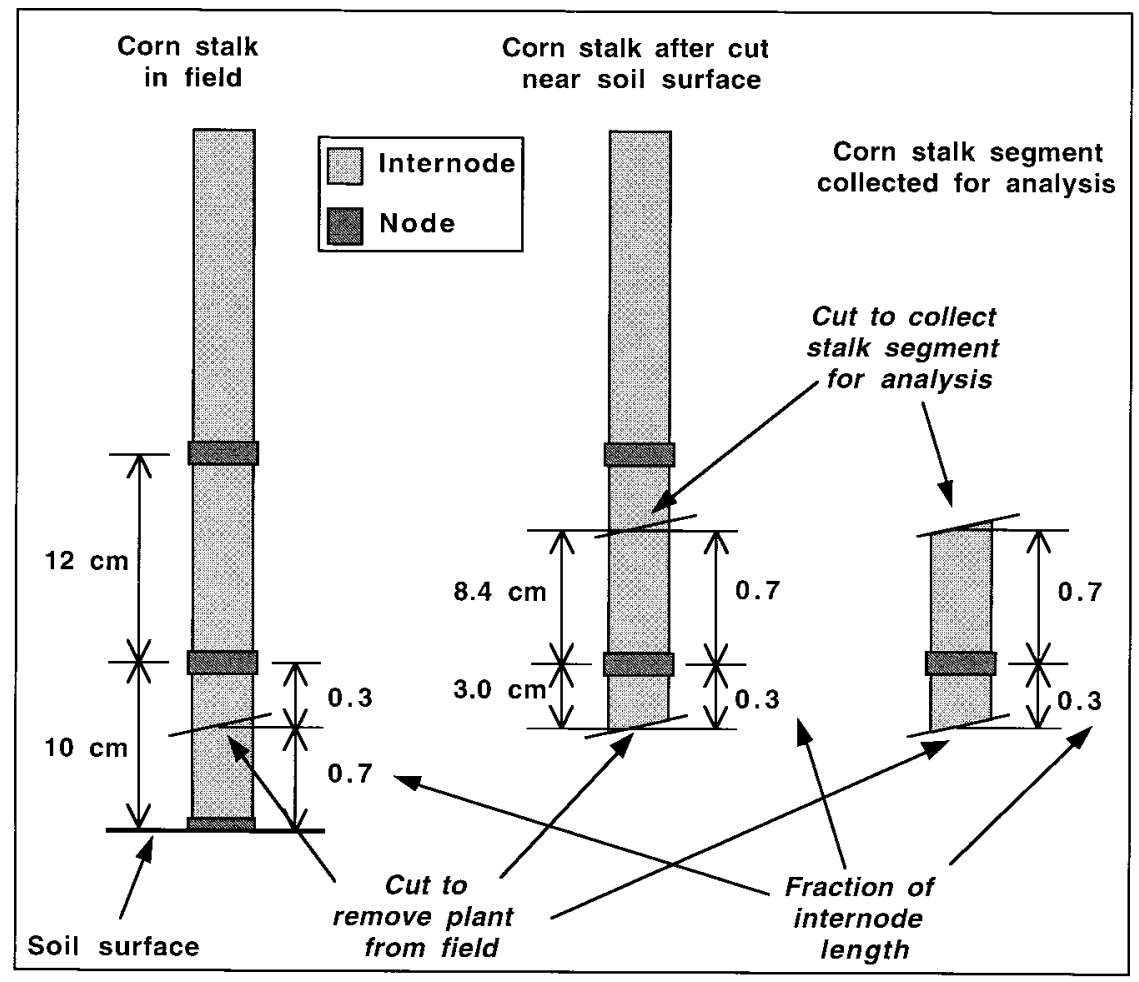

Fig. 1. Diagrammatic description of the method used to collect stalk segments composed of one node and approximately one internode. (An internode may be composed of a portion of the internodes below and above the node.) 


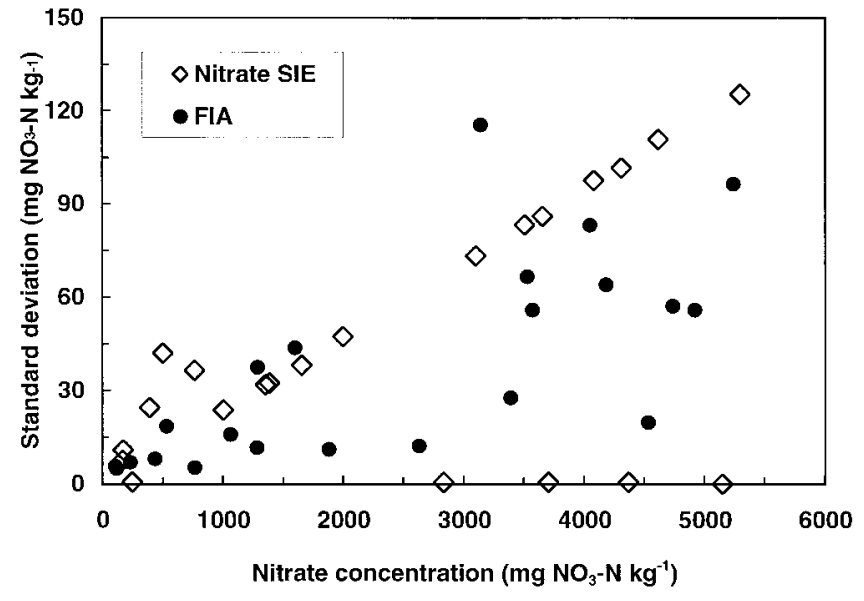

Fig. 2. Mean and standard deviation for stalk $\mathrm{NO}_{3}-\mathrm{N}$ concentration measured by flow injection analysis (FIA) and $\mathrm{NO}_{3}$ specific ion electrode (SIE) methods.

their estimates of $\mathrm{NO}_{3}$ concentration and how the differences affected interpretation of the end-of-season stalk $\mathrm{NO}_{3}$ test.

\section{RESULTS AND DISCUSSION}

To be useful as an alternative method for assessing stalk $\mathrm{NO}_{3}$ concentration, the $\mathrm{NO}_{3}$ SIE method must have two characteristics. First, mean values must be similar to those found by methods assumed to be the standard (FIA). Secondly, estimates of $\mathrm{NO}_{3}$ concentration must be repeatable.

We will address the second question first. Though we expected FIA to provide more precision than the $\mathrm{NO}_{3}$ SIE, mean standard deviations (3 extractions and analyses on each of 22 samples) for the two methods were similar; $37.5 \mathrm{mg} \mathrm{NO}-\mathrm{N} \mathrm{kg}^{-1}$ for FIA and $44.3 \mathrm{mg}$ $\mathrm{NO}_{3}-\mathrm{N} \mathrm{kg}^{-1}$ for the $\mathrm{NO}_{3}$ SIE. Sample $\mathrm{NO}_{3}-\mathrm{N}$ concentrations ranged from about 100 to $5300 \mathrm{mg} \mathrm{kg}{ }^{-1}$. These standard deviations values may seem large; however, when they were converted to coefficients of variation and expressed as percent of the mean, the precision of both methods was very acceptable $(1.5 \%$ for FIA and $1.8 \%$ for $\mathrm{NO}_{3} \mathrm{SIE}$ ). Visual examination of the relationship between standard deviations and means (Fig. 2) appears to show a stronger association between these parameters for the $\mathrm{NO}_{3}$ SIE than for FIA. However, when linear correlation coefficients were computed the reverse was found: For the $\mathrm{NO}_{3}$ SIE method, $r=0.52$ $(P=0.0141, n=22)$; for the FIA method, $(r=0.72$, $P=0.0002, n=22)$. This apparent contradiction was caused by the strong influence of five samples that showed very little variation with the $\mathrm{NO}_{3}$ SIE (i.e., the five points falling on the $x$-axis in Fig. 2). When these points were removed, results of the correlation analysis agreed with our visual assessment. The recalculated correlation coefficient for the $\mathrm{NO}_{3}$ SIE method was $r=$ $0.98(P<0.0001, n=17)$. The reason for several points having no variation is largely an artifact of the use of a digital electrometer to measure output from the $\mathrm{NO}_{3}$ SIE. The meter cannot display very small differences between samples. Therefore, the meter readout was the same for all samples and the variation was calculated

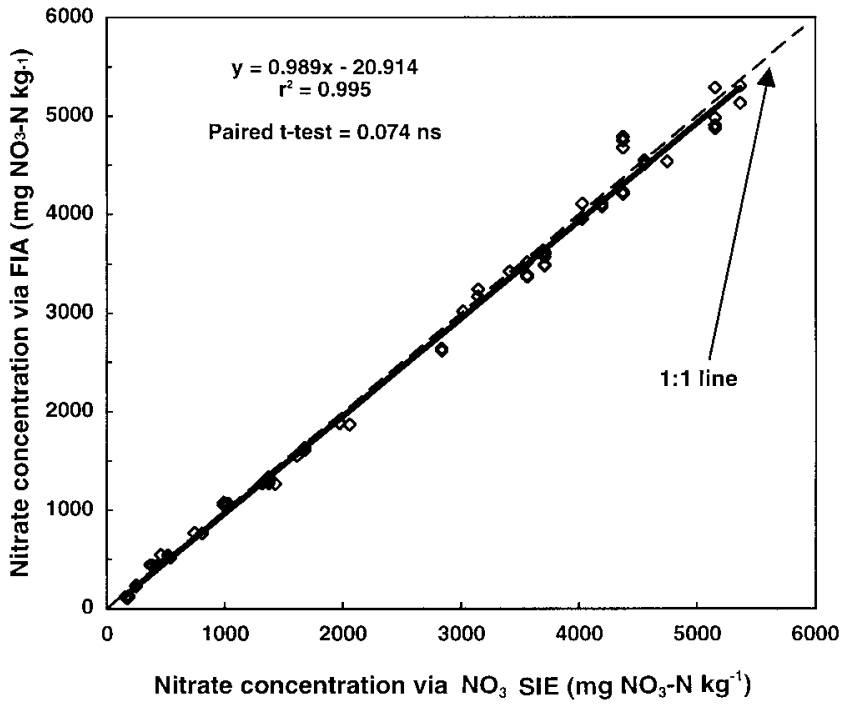

Fig. 3. Comparison of stalk $\mathrm{NO}_{3}-\mathrm{N}$ concentrations estimated by flowinjection analysis (FIA) and $\mathrm{NO}_{3}$ specific ion electrode (SIE) methods.

to be zero. The purpose of the stalk $\mathrm{NO}_{3}$ test is to determine if $\mathrm{NO}_{3}-\mathrm{N}$ concentrations are less than 700 $\mathrm{mg} \mathrm{kg}^{-1}$ or greater than $2000 \mathrm{mg} \mathrm{kg}^{-1}$. Therefore, the inability to detect small differences between samples and a strong correlation between the mean and standard deviation of measurements (undesirable characteristics for analytical procedures) have little bearing on the usefulness of the technique.

To the first question: Are $\mathrm{NO}_{3}-\mathrm{N}$ concentration estimates with the $\mathrm{NO}_{3}$ SIE similar to those from the standard method (FIA)? Slope of the linear fit of $\mathrm{NO}_{3}$ SIE estimates of stalk $\mathrm{NO}_{3}-\mathrm{N}$ concentrations to those estimated with FIA was not different from $1.0[t=1.25(\mathrm{NS})$, $\alpha=0.05$, df $=20$; Fig. 3]. In addition, the $t$-test of the paired analyses indicated no bias in the estimates $[t=$ $0.074(\mathrm{NS}), \alpha=0.05, n=22$ ]. Analysis of variance of stalk $\mathrm{NO}_{3}-\mathrm{N}$ concentrations measured by FIA and $\mathrm{NO}_{3}$ SIE indicated the two methods differed (flow injection, $2419 \mathrm{mg} \mathrm{NO}{ }_{3}-\mathrm{N} \mathrm{kg}^{-1} ; \mathrm{NO}_{3}$ SIE, $2467 \mathrm{mg} \mathrm{NO}{ }_{3}-\mathrm{N} \mathrm{kg}^{-1}$; $P<0.001)$. Though these means were different, the $\mathrm{NO}_{3}$ SIE estimate is less than $2 \%$ greater than the estimate from FIA. When a difference of less than $2 \%$ is found to be significant, the results more reflect the precision of both methods than a lack of accuracy in either. These results indicate that, although absolute $\mathrm{NO}_{3}$ concentration determined by the two methods may differ slightly, the relative values and their rank will be similar. Results certainly indicate that the $\mathrm{NO}_{3} \mathrm{SIE}$ can repeatedly, and reliably, be used to determine if $\mathrm{NO}_{3}-\mathrm{N}$ concentrations of samples are less than $700 \mathrm{mg} \mathrm{kg}^{-1}$ or greater than $2000 \mathrm{mg} \mathrm{kg}^{-1}$.

In conclusion, these data indicate that stalk $\mathrm{NO}_{3}-\mathrm{N}$ concentration estimated by the two methods may differ slightly. The strong relationship between results produced by the methods indicates that any discrepancy between methods would be small and within the requirements for the end-of-season stalk $\mathrm{NO}_{3}$ test. In addition, savings in terms of equipment costs and time for sample preparation could be substantial. Use of hazardous 
chemicals is also eliminated: There is no need for strong acids and bases, nor for the carcinogen $\mathrm{Cd}$.

\section{ACKNOWLEDGMENTS}

We express gratitude to Susan Wagner for her efforts in conducting much of the laboratory work associated with this study.

\section{REFERENCES}

Binford, G.D., A.M. Blackmer, and N.M. El-Hout. 1990. Tissue test for excess nitrogen during corn production. Agron. J. 82:124-129.
Binford, G.D., A.M. Blackmer, and B.G. Meese. 1992. Optimal concentration of nitrate in cornstalks at maturity. Agron. J. 84:881-887.

Keeney, D.R., and D.W. Nelson. 1982. Nitrogen: Inorganic forms. p. 643-698. In A.L. Page et al. (ed.) Methods of soil analysis. Part 2. 2nd ed. Agron. Monogr. 9. ASA and SSSA, Madison, WI.

Orion Research. 1980. Nitrate in soils, plants, and fertilizers. Procedure 103. Orion Res., Cambridge, MA.

Varvel, G.E., J.S. Schepers, and D.D. Francis. 1997. Chlorophyll meter and stalk nitrate techniques as complimentary indices of residual nitrogen. J. Prod. Agric. 10:147-151.

Wilhelm, W.W., and B.E. Johnson. 1997. Nitrogen fertilizer management for hybrid seed production fields. p. 189-205. In Proc. Corn Sorghum Res. Conf., 52nd, Chicago. 10-11 Dec. 1997. Am. Seed Trade Assoc., Washington, DC.

\section{LETTER FROM THE EDITOR}

The Agronomy Journal (AJ) Editorial Board approved several measures at our annual Editorial Board meeting on 3 Nov. 1999 in Salt Lake City, UT, that will enhance the prestige of our journal. We adopted the following changes and recommendations: (i) exempt "double-blind" reviews of Software papers; (ii) continue to allow electronic submissions, but with formatting restrictions; (iii) recognize outstanding reviewers; and (iv) develop the concept of "Implication Summaries" that we would publish on the American Society of Agronomy (ASA) Web site.

Double-Blind Exemption of Software Papers. Because authors who submit Software papers often need to refer reviewers or readers to an email address or Web site where software or support can be found, identification of the authors will probably result. Consequently, we adopted a policy of exempting Software manuscripts from the double-blind review. In the December issue of Crop Science-Soil Science-Agronomy News, we alerted Software authors that their papers may not receive a double-blind review unless they carefully remove references in Web sites, etc. that may identify them.

Electronic Submission. The AJ Editorial Board approved the continuation of electronic submissions for another year. We will accept only those electronic submissions that are PDF files and are formatted for our "double-blind" review. Authors may again submit the manuscript via email to Dr. Robert Lascano, one of our Technical Editors. Dr. Lascano would then forward the paper to the proper subject matter Technical Editor and the paper would proceed through the review process in the same manner as hard copy submissions.

Recognition of Outstanding Reviewers. The scholastic integrity of AJ depends on competent scientific reviews. We are developing a program to acknowledge those reviewers who provide outstanding comments and suggestions that help authors improve the quality of their manuscripts. We are currently developing the criteria for selection and for the recognition process.

Implication Summaries. We approved the concept of a shortened, lay version of accepted AJ manuscripts that we are initially calling "Implication Summaries." The idea is to develop a vehicle that would interest agronomic practitioners and the general public and allow authors to communicate the

Published in Agron. J. 92:189 (2000). practical relevance of their research. We adopted the following aspects of these summaries: (i) they will be voluntary for each manuscript's author(s), (ii) we will post them on the ASA Web site for free access, and (iii) the Web site will contain a search engine for locating specific topics or authors. We also forwarded a suggestion to the ASA Board of Directors to invite participation in posting these types of summaries for all journals associated with ASA, Crop Science Society of America, and Soil Science Society of America. The AJ Editorial Board is currently developing the details for this Webbased publication.

Incorporation of Journal of Production Agriculture (JPA) into AJ. Since January 1999, AJ has been accepting papers for review that would previously have been submitted to JPA. The ASA Board of Directors voted to discontinue publication of JPA at our 1998 Annual Meetings; consequently, AJ expanded its scope to include production agriculture papers. We added a Technical Editor and eight Associate Editors to handle the production agriculture manuscripts.

Forum and Review Papers. I want also to remind you of two important types of submissions that we consider for publication in AJ. Forum papers are designed "to provide a venue for discussion and presentation of current agronomic issues." We also publish Review papers that look at a scientific concept using extensive and thorough interpretation of literature and possibly previously unpublished information. We encourage submission of these kinds of papers to the Editor for review; we believe that they could enhance the exchange of ideas and scientific information that could generate exciting discussions.

I welcome any comments that you have about our changes in AJ or other concerns regarding our journal. We also encourage you to submit manuscripts for possible publication, to review submitted papers, and to serve on our Editorial Board. I believe that the most significant contribution we can make to our professional society is to serve in the review process of our journals. I look forward to implementing exciting changes in AJ that will better serve our own and society's needs.

\footnotetext{
Kenneth A. Barbarick

Editor, Agronomy Journal

Dep. of Soil \& Crop Sciences

Colorado State University

Fort Collins, CO 80523

kbarbari@agsci.colostate.edu
} 